\title{
CETANE IMPROVERS AND ETHANOL PERFORMANCE AND EMISSIONS CHARACTERISTICS USING PYRORATED BIODIESEL
}

\author{
Maroa Semakula ${ }^{1}$ and Freddie Inambao ${ }^{2}$, \\ 1,2 University of KwaZulu-Natal, Durban South-Africa. \\ ssemakulamaroa@gmail.com;inambaof@ukzn.ac.za
}

\begin{abstract}
Alternative fuels available at low cost, friendly to natural environments and meet the energy needs and demands, have witnessed a growing demand and use today. Ethanol is an attractive renewable energy source with a high content of oxygen. Ethanol can be produced through ethanolisis, however for this work direct blending of conventional diesel, waste plastic pyrolysis oil and ethanol with commercial fuel improver CI-0808 purchased from Innospec company was attempted. The primary purpose of adding a cetane improver was to improve the combustion characteristics of the blends by at least 1- 3 ignition quality points. Five mixing ratios were chosen in the following order, 50:25:25, 60: 20:20, 70: 15:15, 80: 10:10 and 90: 5:5 for Waste Plastic Pyrolysis Oil (WPPO), ethanol and conventional diesel (CD) respectively. However, for the fuel additive mixing ratio the total volume percentage was considered and the ratio put at $0.01 \%$ of the total quantity of blended fuel. In this work WPPO, diesel blends and fuel additives improvers were used as alternative fuel. This was to evaluate their performance and emission characteristics in a stationary single cylinder water cooled experimental diesel engine. The CI-0808 was added due to its potential power to reduce emissions of CO, UHC, $\mathrm{NO}_{\mathrm{x}}, \mathrm{PM}$ and improved engine performance. The results obtained were compared carefully to ASTM standards and discussed using graph curves figures and tabulated values. The conclusion was that ethanol and WPPO blends can be used in diesel engines as alternative fuel without modification. Used in combination with cetane improvers the emissions reduce significantly and performance improved equalling that of conventional diesel fuel.
\end{abstract}

KEY WORDS: Carbon Dioxide, Carbon Monoxide, Cetane Improver, Ethanol, High Content of Oxygen, Ignition Quality, Waste Plastic Pyrolysis Oil. 


\subsection{INTRODUCTION}

The sharp rise in the number of automobile personal transportation has significantly increased the demand for energy especially in the primary sources of energy. Therefore, it has become imperative and important to seek alternative solutions to meet this need of increasing energy demand associated with modern day development. Since the discovery of the diesel engine by Rudolph Diesel in 1893, diesel engines have proved themselves as superior, power efficient and with good fuel economy compared to gasoline engines. However, despite all advantages diesel engines have continually been accused and proven guilty of emitting high emission levels of $\mathrm{NO}_{\mathrm{X}}, \mathrm{CO}_{2}, \mathrm{UHC}, \mathrm{PM}$ and smoke emissions. These emissions have been shown not only to affect human health but also the environmental health especially atmospheric air and land [1].

Diesel exhaust is now classified as carcinogenic [2] to humans and exposure has been linked to increased risk to lung cancer and cardiovascular diseases [3]. Besides human effects diesel exhaust emissions is considered the primary source of providing ground level ozone [4], sick building syndrome [5], acid rain [6] and smog [7]. Therefore, the road to find an alternative source of fuel energy with desirable characteristics as those of petroleum based fossil fuels cannot be emphasized [8]. Early alternatives developments in fuel energy studies utilized food based sources as alternatives to petroleum fuels. However due to the poor food security in most developing countries this development has faced opposition and arguments from all sectors and the world leading organizations such as FAO and the united nations security council on human rights. The first generation food based biodiesels lead to cultivation of large swathes of land for commercial purposes eventually supressing the edible food crop acreage. Consequently this increased food insecurity leading to increased food prices and economic inflation as reported by [9].

However, when it comes to second generation biodiesel fuels especially the higher alcohols it has been observed they can be produced from biomass lignocellulosic sources like wood, waste cooking oil and non-edible oils, thus minimizing or eliminating the issue of food security associated with first generation biodiesels. This biodiesel fuel or higher alcohols portend merits that have made them quite appealing to more researchers such as better miscibility, better blend stability with diesel, high energy density and low cost of production due to lower energy production cost requirements when commercially producing alcohols [10]. This is in comparison to the demerits of low alcohols such as low energy density, high volatility, poor lubricity, high hygroscopicity and low solubility at low temperatures. Density is an important fuel component property which directly affects engine performance $[11,12]$ and sometimes even emission characteristics. Most fuel properties like heating values and cetane numbers are related to the density of the fuel. It's the density of the fuel that influences efficiency, atomization and combustion characteristics [13]. Consequently, any change in density of fuel affects and influences the power output of an engine as the mass of the injected fuel changes with change in density. Lower density and viscosity is responsible for poor lubricity of most of the bioethanol-diesel blends. In other words when the bioethanol is mixed with diesel the resulting mixture results into a low grade fuel [14].

Research on WPPO has shown that using the technique of pyrolysis to extract liquid fuel from plastic waste material is a viable alternative to diesel fuel production. This is true especially when waste plastic oil is used with fuel additives [15]. Statistics show that as of 2016 , only a paltry $9 \%$ world wide of waste plastic has been recycled with almost $80 \%$ going to landfills to continue degrading the natural environment as plastics are non-biodegradable. This is quite a poor response and alarming as the gap between generation and recycling continues to grow huge, thus requiring bridging [16]. Plastic pyrolysis can also be done using catalytic pyrolysis and the thermal processes. The catalytic method uses low levels of temperature to cause plastic degradation and decomposition compared to the thermal technique which requires very high temperature to produce high and greater liquid fuel. This has helped 
in recycling waste into energy, a development that has been captivated and motivated current crop of researchers such as [17-19] and many more others in the preceding sections.

Production of WPPO by pyrolysis has proven itself as the most cost effective option in the extraction process for plastic waste that produces high good yield percentages compared to other plastic waste extraction methods as reported by [20]. However, production of higher alcohols which have been shown to be good additives to waste plastic fuels has been shown to be produced using biological pathways. This is where microbial or anaerobic fermentation of engineered micro-organisms in a chemical laboratory can be used on lignocellulosic biomass. Materials such as, rice straw, corn stocks, wood pulp and sugar cane bagasse [21] can be used to produce biodiesel without resorting to food crops based biodiesel. Biomass can be easily gasfied or steam reformed or partially oxidized in order to produce synthesis gases such as $\mathrm{CO}, \mathrm{H}_{2}$ and $\mathrm{CO}_{2}$. By an addition of a catalyst, these gases are converted into high level alcohols by a process called high alcohol synthesis (HAS) [22]. However $[23,24]$ have expanded the understanding on the synthesis via syngas fermentation by application of catalysts leading to higher yield of n-pentanol. This high yield alcohol n-pentanol when added to WPPO blends has been reported to improve oxygen concentration and injection spray characteristics [25]. This causes the WPPO to ignite quite easily, improve the fire point qualities and the combustion behaviour and characteristics. The use of higher level alcohols in the early stages of research and development was slow due to the exorbitant cost of production and wide use in the food industry [26].

As a result of growing concern over fossil fuel depletion, oil prices fluctuations, escalating energy demands and stringent emission regulation and control. The research family has been pushed to search for better alternative renewable resources of energy, as a replacement for fossil based petroleum diesel fuel as a source of primary energy [9]. The use of lower alcohols methanol and ethanol have had certain limitations due to their low cetane numbers, high latent heat of vaporization and high resistance to auto-ignition [27]. However, in order to deal with the limitations including low calorific value, poor miscibility with diesel fuel, and poor lubricity [28]. Several methods have been proposed and they include alcohol fumigation, dual fuel injection, alcohol diesel blends and alcohol diesel-emulsion in order to handle this limitations and demerits [29]. The reduction in smoke emissions and opacity is directly linked to the oxygen content of the blends of diesel and alcohol produced as observed by [30]. Alcohols are classified under oxygenated fuels with a hydroxyl $(\mathrm{OH})$ group. The availability of oxygen inherent in their molecular structure during combustion reduces smoke emissions in diesel engines particularly during high engine loads as reported by [31]. There has been a recent increase in the awakening of interest in higher level alcohols due to their high energy demand, higher cetane numbers, better blend stability, less hygroscopic tendencies, increased carbon chain length and improved ignition quality of the alcohol fuel molecules [32], compared to the lower alcohols ethanol and methanol.

The last decade has witnessed tremendous renewed and reinvigorated interest in higher level alcohols as a sustainable option in reducing dependency on the lower alcohols and fossil fuels. Through research and collaboration with various biotechnology research groups there has been improvement in the yield of higher level of alcohols through processing cellulose by modern fermentation processes such as using clostridium species [33], biosynthesis from glucose using genetically engineered microorganisms like Escherichia coli [34], cyanobacteria [35] and saccharomyces cerevisiae [36].

There are a number of researchers who have used fuel additive in their work on WPPO biodiesel and other biodiesels:[25, 28, 31, 37-53].[54] studied how to reduce $\mathrm{NO}_{\mathrm{X}}$ and $\mathrm{PM}$ emissions in a diesel engine. To achieve this aim they employed both ethanol and selective catalytic reduction over catalyst $\mathrm{Ag} / \mathrm{Al}_{2} \mathrm{O}_{3}$, using blends of biodiesel-ethanol fuel (BE). These researchers reported increased UHC, $\mathrm{CO}$ and PM emissions of $14 \%$ due to the increase in the SOFs in the PM emissions. However, they additionally reported the Bosch smoke number reduced by between $60 \%$ to $80 \%$ based on the ESC standard. Consequently, the $\mathrm{NO}_{\mathrm{x}}$ emissions were reduced by a significant margin of $73 \%$, thus leading 
them to conclude that a combination of BE and SCR catalyst arrangement could provide a good platform for $\mathrm{NO}_{\mathrm{x}}$ and $\mathrm{PM}$ reduction and control.

[55] studied to determine cold flow features and characterization of ethanol based biodiesel compared to diesel fuel. Their study presented the relationship of these fuels to torque, brake thermal efficiency, BSFC and emission characteristics in diesel engines. As a result of their research work in the last decade, developed and emerging countries have now made it mandatory for instance in Europe and America for fuel manufacturers and distributors to add between $1 \%$ to $5 \%$ biofuel to most commercially available diesel fuel. In the united states of America, the renewable fuel standard (RFS) program now requires blending of advanced biofuels in an increasing amount, with fossil fuel used in transportation. The government has been targeting to achieve an annual projection growth escalation of 36 billion gallons by the year 2022 [56].

Therefore, this work seeks utilization of development in fuels that are derived from renewable feedstock sources such as municipal solid waste (MSW) disposed plastics. In addition, it will include lignocellulosic feedstock like ethanol and others in this category as best placed alternative to replace petroleum based fossil fuels like diesel commonly used as the primary propulsion fuel in the transport industry and power generation. Plastics have a lot of stored potential energy of hydrocarbons inherent in their molecular structure, thus by altering them through modern methods of decomposition, they can be converted to liquid fuels. This can be done through such processes as de-polymerization and pyrolysis to provide the alternative fuel energy source need [57].

\subsection{EXPERIMENTAL SET-UP}

The experimental setup consists of a diesel engine, gas analyser and a smoke meter. The engine used in the experiment is a constant speed Kirloskar engine, four stroke single cylinder, direct injection vertical tilting diesel engine. The engine is water cooled and rated at $3.75 \mathrm{~kW}$ at $1500 \mathrm{rpm}$ with torque of $28 \mathrm{Nm}$. An electric dynamometer was used to apply engine load to the test engine by means of a loading device. The engine is mounted on concrete bed with suitable modification connections for water cooling and engine lubrication. The outlet temperature of water from engine is maintained at 85 ${ }^{\circ} \mathrm{C}$ to $90 \mathrm{C}$ by adjusting the flow of the coolant and insulating the outlet pipe. The schematic arrangement of experimental setup is shown in Fig.1. Data collection is done through a data collection machine with the aid of a computer interface and in built LabVIEW software application.

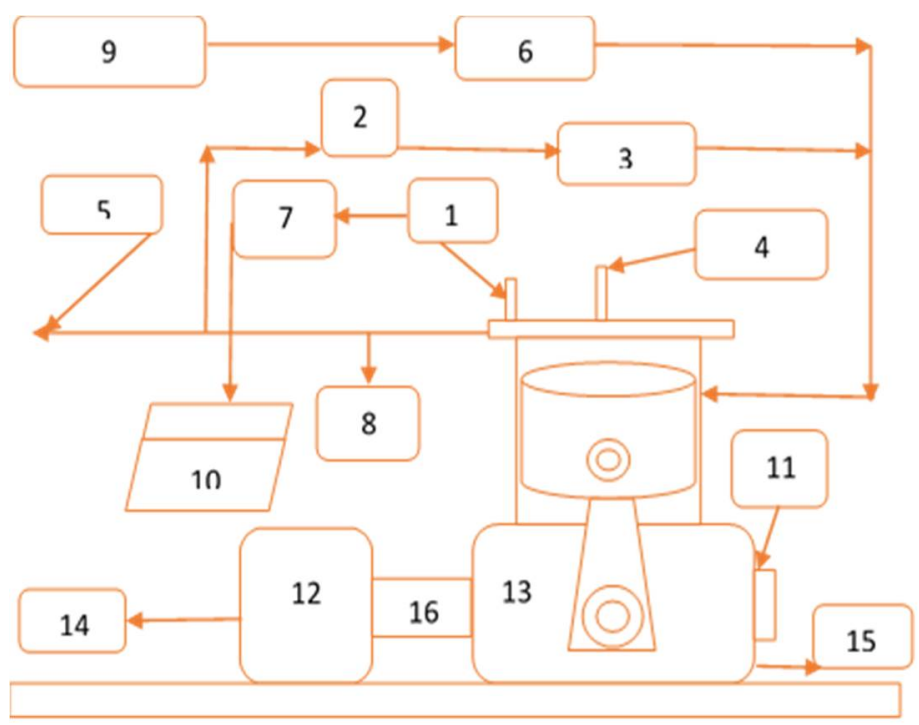

Fig.1. Schematic diagram of the test engine set up rig 
Table I. Experimental engine specifications

\begin{tabular}{ll}
\hline Parameters & Position value \\
\hline Ignition Type & 4 (Stroke)DICI \\
Number Of Cylinders & 1 \\
Model & TV 1 \\
Cooling Medium & Water \\
Manufacturer & Kirloskar \\
Revolutions Per Minute & 1500 \\
Brake Power & $3.5 \mathrm{~kW}$ \\
Cylinder Bore & $87.5 \mathrm{~mm}$ \\
Piston Stroke & $110 \mathrm{~mm}$ \\
Compression Ratio & $18.5: 1$ \\
Connecting-Rod Length & 234 \\
Engine Capacity & $661 \mathrm{cc}$ \\
Dynamometer Make & 234 \\
Injection Timing & 23.4 bTDC \\
Maximum Torque & $28 \mathrm{Nm} \mathrm{@1500}$ \\
Injection Pressure & $250 \mathrm{Bar}$ \\
\hline
\end{tabular}

Table II. Properties of Diesel, WPPO and ethanol

\begin{tabular}{lllll}
\hline PROPERTIES & UNIT & CD & WPPO & ETHANOL \\
\hline $\begin{array}{l}\text { Density @ } \\
\text { 20 C }\end{array}$ & $\mathrm{kg} / \mathrm{M}^{3}$ & 845 & 825 & 792 \\
Visc.@ $40 \quad \mathrm{C}$ & $\mathrm{cSt}$ & 3.04 & 2.538 & 1.05 \\
Cetane Number & - & 55 & - & 8.5 \\
Flash Point & $\mathrm{C}$ & 50 & 43 & 16 \\
Fire Point & $\mathrm{C}$ & 56 & 45 & 53 \\
Carbon residue & $\%$ & 22 & 0.015 & - \\
Sulphur content & $\%$ & $<0.028$ & - & - \\
Gross Calories & $\mathrm{kJ} / \mathrm{kg}$ & 46500 & 43340 & 29700 \\
Cetane index & - & 46 & 65 & - \\
\hline
\end{tabular}

Table III. Properties of blended fuels diesel, ethanol, WPPO and fuel additive CI-0808

\begin{tabular}{lccc}
\hline PROPERTIES & UNIT & E/WPPO/CD & $\begin{array}{l}\text { E/WPPO/D/CI- } \\
0808\end{array}$ \\
\hline $\begin{array}{l}\text { Density } \\
\text { viscosity@20 }\end{array}$ & $\mathrm{Kg} / \mathrm{M}^{3}$ & 835 & 833 \\
$\begin{array}{l}\text { Cetane } \\
\text { Number }\end{array}$ & $\mathrm{C}$ & 2.38 & 2.37 \\
$\begin{array}{l}\text { Carbon } \\
\text { Residue }\end{array}$ & - & 54 & 62 \\
Sulphur & $\%$ & 0.013 & 0.014 \\
\hline
\end{tabular}




\subsection{RESULTS AND DISCUSSION}

\subsection{Brake Specific Fuel Consumption (BSFC)}

Fig.1 is a variation of BSFC with engine load. The BSFC compared to the engine load in Fig.1 reveals or shows that as the load increases there is increase in the amount of fuel consumed by the test engine as revealed in the graph in Fig.1. The values obtained at full engine load for the blends of 90/WPPO5/E5, 80/WPPO10/E10,70/WPPO15/E15, 60/WPPO20/E20, 50/WPPO25/E25 and CD were $0.04 \mathrm{~g} / \mathrm{kW} . \mathrm{h}, 0.041 \mathrm{~g} / \mathrm{kW} . \mathrm{h}, 0.042 \mathrm{~g} / \mathrm{kW} . \mathrm{h}, 0.043 \mathrm{~g} / \mathrm{kW} . \mathrm{h}$ and $0.035 \mathrm{~g} / \mathrm{kW} . \mathrm{h}$ respectively.

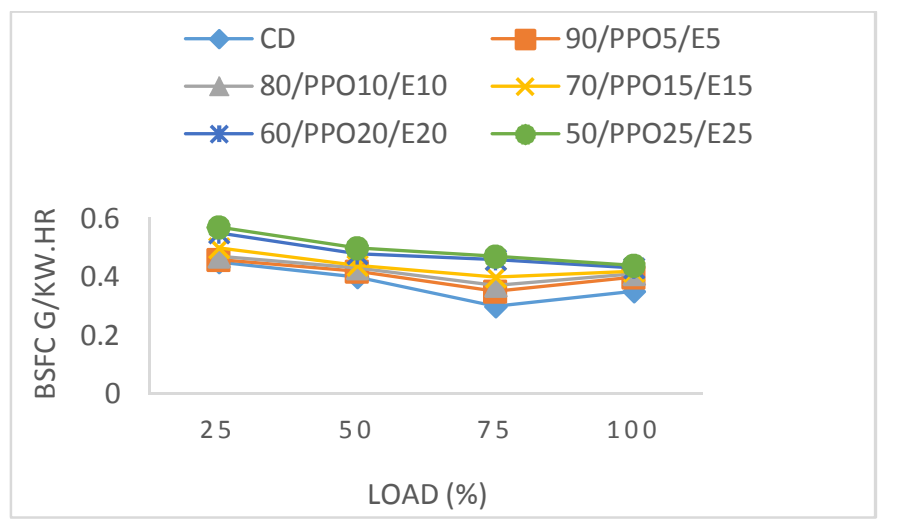

Fig.1. Brake specific fuel consumption versus load

As the blend ratio increased there was a decrease in the BSFC across all the test fuels although the values for all WPPO blends were slightly higher compared to CD test fuel. The closeness of the values and the packed graph reveal a close resemblance and identical BSFC characteristics of WPPO, ethanol and fuel additives compared to $\mathrm{CD}$ fuel. For example, at $50 \%$ engine load the blend of 80/WPPO10/E10 had a value of $0.043 \mathrm{~g} / \mathrm{kW}$.h compared to full engine load with $0.041 \mathrm{~g} / \mathrm{kW}$.h., this value is higher than CD test fuel with $0.04 \mathrm{~g} / \mathrm{kW}$.h at $50 \%$ engine load and $0.035 \mathrm{~g} / \mathrm{kW} . \mathrm{h}$ at full engine load.

\subsection{Brake Thermal Efficiency (BTE)}

The BTE variations with engine load are shown in Fig.2. The graphs show that as the load increased there was increase in the BTE across all the test fuel blends of WPPO and CD. At $50 \%$ engine load thevaluesforblends90/WPPO5/E5,80/WPPO10/E10, 70/WPPO15/E15,60/WPPO20/E20, 50/WPPO25/E25 and CD were $22 \%, 21,20 \%, 18 \%, 16.5 \%$ and $22.5 \%$ respectively. As the blend ratio and engine load increased, there was increase in BTE across the blends of WPPO but with a decrease in the BTE within the blends. At $25 \%$ engine load 90/WPPO5/E5 had values of $14 \%, 22 \%$, $26.5 \%$ and $25 \%$ compared to 70/WPPO15/E15 with $12.5 \%, 20 \%, 22.5 \%$ and $23 \%$ respectively.

The highest BTE value was $25 \%$ reported by blend 90/WPPO5/E5 at engine full load compared to any other blend of WPPO and ethanol. Fig. 2 shows values of $24.8 \%, 23 \%, 21 \%$ and $19 \%$ respectively for blends 80/WPPO10/E10,70/WPPO15/E15, 60/WPPO20/E20, 50/WPPO25/E25. However, blend 50/WPPO25/E25 reported the lowest values compared to the other blend. At $25 \%$ engine load the BTE value was $9.5 \%$ compared with full load at $19 \%$, this are the lowest values of BTE as shown in Fig.2. 


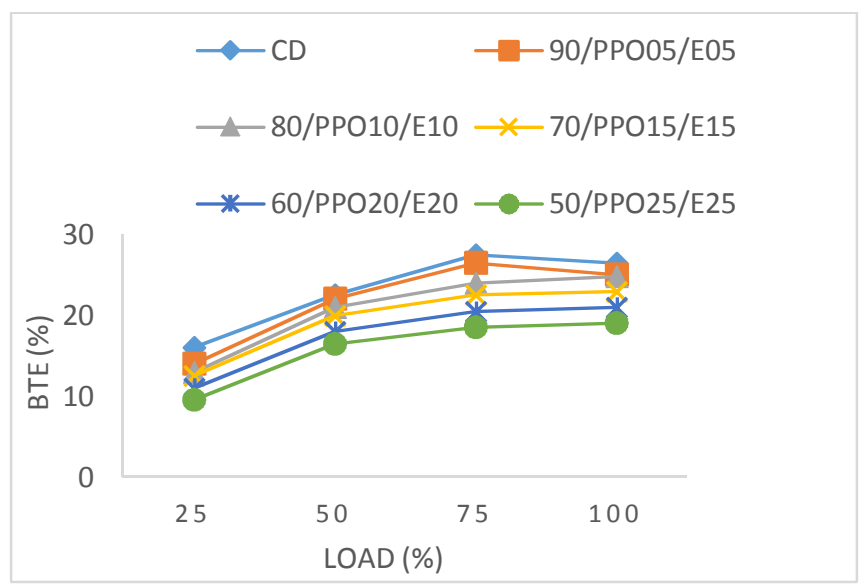

Fig.2. Brake thermal efficiency versus load

\subsection{Exhaust Gas Temperature (EGT)}

The variation of the EGT and the engine load is shown in Fig.3. The graph reveals that as the load increases the value of the EGT increased significantly especially for the blends. At $25 \%$ engine load the blends 90/WPPO5/E5, 80/WPPO10/E10,70/WPPO15/E15, 60/WPPO20/E20, 50/WPPO25/E25 reported values of $165 \mathrm{C}, 195 \mathrm{C}, 226 \mathrm{C}$ and $256 \mathrm{C}$ compared to $\mathrm{CD}$ with $155 \mathrm{C}, 175 \mathrm{C}$, $205 \mathrm{C}$ and $240 \mathrm{C}$ for all engine load conditions.

As the engine load increased from $25 \%$ to full load (100\%) the graph curves tend toward unitary and similar to the values of CD test. This can be concluded that the blends of WPPO, ethanol and fuel additives have identical temperature characteristics to those of CD test fuel especially as the engine load hits $75 \%$ heading to $100 \%$ (full load).

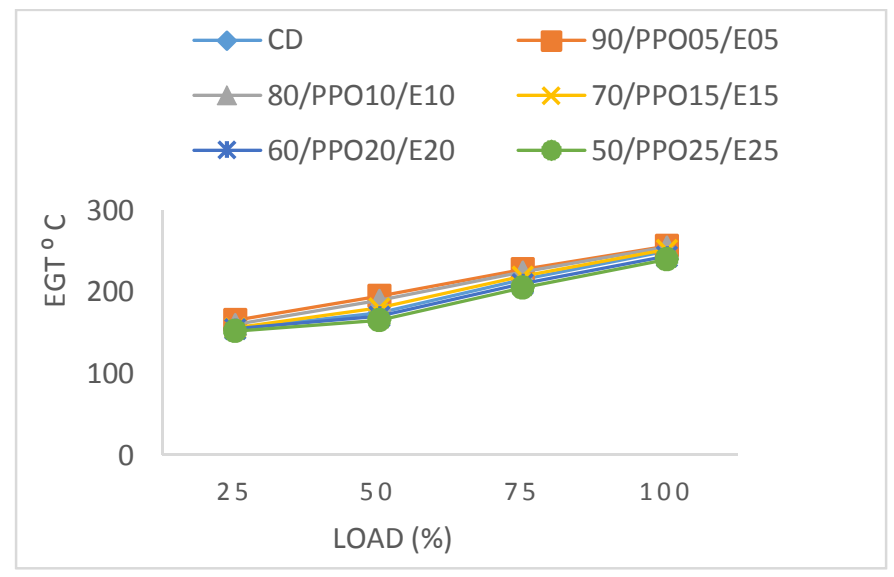

Fig.3. Exhaust gas temperature versus load

\subsection{Carbon Monoxide (CO)}

Fig.4 is a variation of $\mathrm{CO}$ with engine load. The graph reveals that as the engine load and the blend ratio increased the values of blends 90/WPPO5/E5, 80/WPPO10/E10, 70/WPPO15/E15, 60/WPPO20/E20, 50/WPPO25/E25 had CO emissions decreased up to $75 \%$ of engine load. There after the blends reported a continuous increase as the engine load was approaching full load. At $25 \%$ 
engine load the blends of 90/WPPO5/E5, 80/WPPO10/E10, 70/WPPO15/E15, 60/WPPO20/E20, 50/WPPO25/E25 reported values of $0.055 \%, 0.0565 \%, 0.06 \%, 0.0615 \%$ and $0.0625 \%$.

However, as the load is increased to $75 \%$ the values are $0.035 \%, 0.0375 \%, 0.0445 \%$ and 0.0 .0475 respectively. At full load all the test fuels showed increased CO emissions with blends 90/WPPO5/E5 and 80/WPPO10/E10 reporting the lowest emissions among the test blends across all the engine load conditions. At $50 \%$ the blends reported values of $0.0445 \%$ and $0.0475 \%$ compared to full load with $0.0425 \%$ and $0.0465 \%$ respectively.

As the engine load and the blend ratio increased there is an increase in the carbon monoxide emission across the all engine loads and within the blends and CD test fuel. At $50 \%$ engine load the values of the blends and $\mathrm{CD}$ were $0.045 \%, 0.0475 \%, 0.0515 \%, 0.0535 \%, 0.0565 \%$ and $0.05 \%$ for 90/WPPO5/E5, 80/WPPO10/E10, 70/WPPO15/E15, 60/WPPO20/E20, 50/WPPO25/E25 and CD respectively. The above values obtained from Fig.4 suggest that there is a reduction of $\mathrm{CO}$ emissions across all test fuel irrespective of blend ratio and type of fuel except at high engine loads exceeding 75 $\%$ to full engine load. After this point there is a steady incr3ease in the emissions of CO.

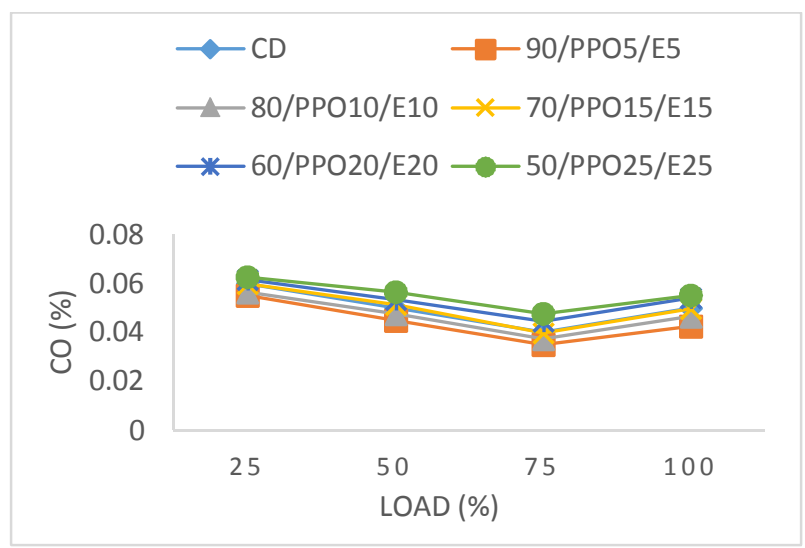

Fig.4. Carbon monoxide versus load

\subsection{Carbon Dioxide $\left(\mathrm{CO}_{2}\right)$}

Fig. 5 is the variation of $\mathrm{CO}_{2}$ with engine load. The graph shows that as the blend ratio and engine load increased $\mathrm{CO}_{2}$ emissions increased, but compared to $\mathrm{CD}$ their emission levels are still lower and almost identical. At $50 \%$ engine load the values of CD, and the blends of 90/WPPO5/E5, 80/WPPO10/E10, 70/WPPO15/E15, 60/WPPO20/E20, 50/WPPO25/E25 were $3.58 \%$, 3.35 \%, $2.95 \%, 2.6 \%, 2.55 \%$ and $2.25 \%$ respectively.

Fig.5 also reveals from its graph plot that as the load increased there was a significant increase in the $\mathrm{CO}_{2}$ emissions across all test fuels, although with lower values as the blend ratio increased. For example, CD fuel had values of $2 \%, 3.85 \%, 5.95 \%$ and $8.95 \%$ for engine loads of $25 \%, 50 \%, 75$ $\%$ and $100 \%$ compared to blend 80/WPPO10/E10 with 1.8, 2.95, 4.85 and 8.55 for a similar load. The blend with the lowest value of $\mathrm{CO}_{2}$ emission was 50/WPPO25/E25 with values of 1.62, 2.25, 3.65 and 7.35 respectively for engine loads of $25 \%, 50 \%, 75 \%$ and $100 \%$ respectively. 


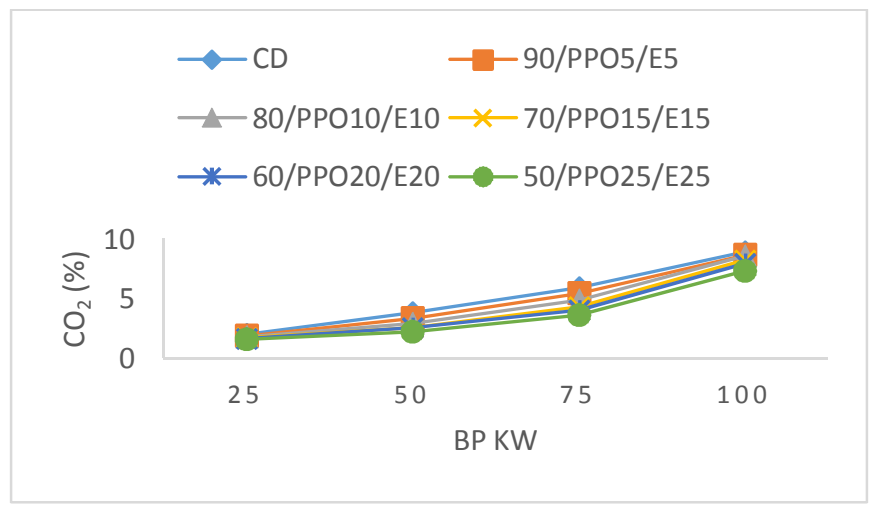

Fig.5. carbon dioxide versus load

\section{6 oxides of nitrogen ( $\left.\mathrm{NO}_{\mathrm{x}}\right)$}

The variation of engine load with $\mathrm{NO}_{\mathrm{x}}$ emissions is shown on Fig.6. The graph plot shows that as the engine load was increased there was increase in the $\mathrm{NO}_{\mathrm{X}}$ emissions irrespective fuel, blend ratio or fuel additive used. However, the value of $\mathrm{NO}_{\mathrm{X}}$ emissions from the blends of ethanol, WPPO and fuel additive reported lower values compared to CD fuel. At $50 \%$ the value of the blends 90/WPPO5/E5, 80/WPPO10/E10, 70/WPPO15/E15, 60/WPPO20/E20, 50/WPPO25/E25 were 385 ppm, 396 ppm, 415 ppm, 445 ppm and 475 ppm, while CD fuel had 425 ppm.

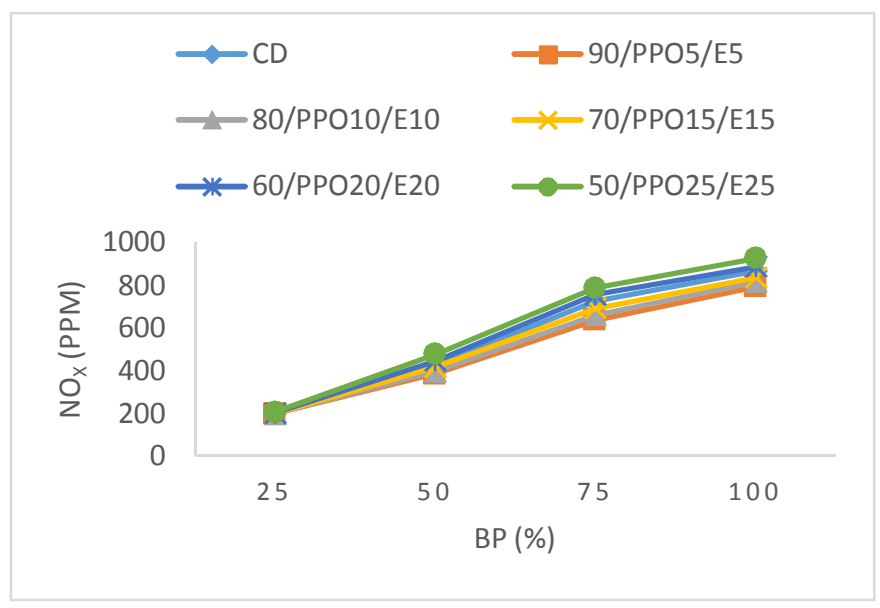

Fig.6. Oxides of nitrogen versus load

Blend 60/WPPO20/E20 and 50/WPPO25/E25 had the highest $\mathrm{NO}_{\mathrm{X}}$ emissions compared to the other blends of 90/WPPO5/E5, 80/WPPO10/E10, 70/WPPO15/E15 across all the engine load conditions tested. At $25 \%$ engine load the two blends had values of $205 \mathrm{ppm}$ and $200 \mathrm{ppm}$ respectively. However, at full engine load the $\mathrm{NO}_{\mathrm{X}}$ emissions values increased to $925 \mathrm{ppm}$ and 885 compared to blend 90/WPPO5/E5 at the same load with 197 ppm and at full load at $792 \mathrm{ppm}$.

From the graph plot in Fig. 6 it is noticed that as the blend ratio increased there was direct increase in the emissions of $\mathrm{NO}_{\mathrm{X}}$ across all the blended test fuels. However, blend 90/WPPO5/E5 reported the lowest values of $\mathrm{NO}_{\mathrm{X}}$ emissions compared to all the other blends that were tested in this experiment. 


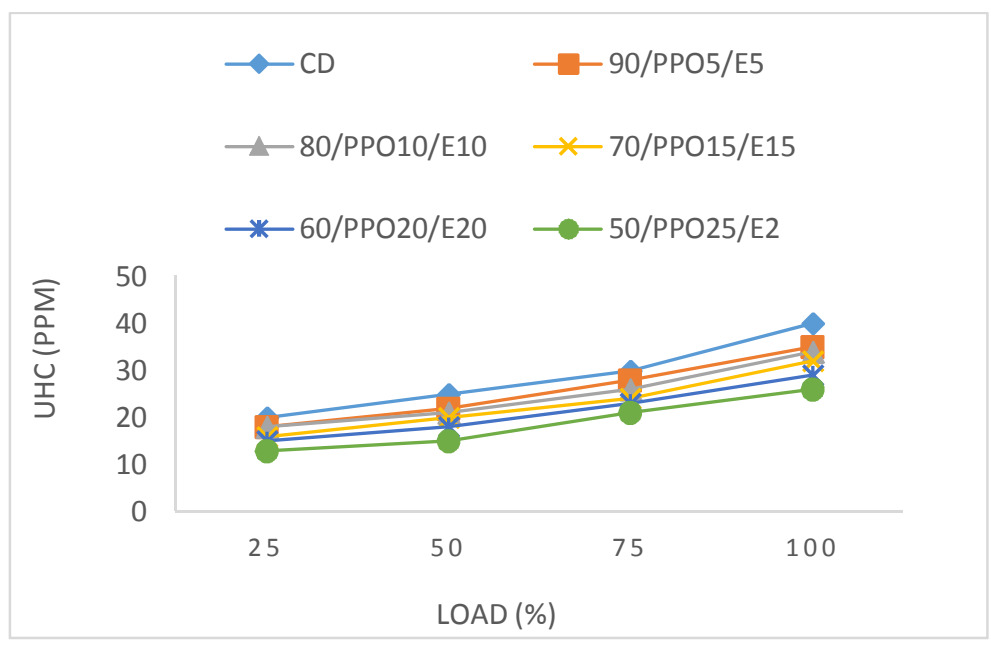

Fig.7. Unburnt hydrocarbons versus load

\subsection{Unburnt Hydrocarbons (UHC)}

Fig.7 is a variation of UHC emission with engine load. As the engine load was increased the UHC emissions increased too. However, the increase is more significant as the engine load was in intermediate loads of $75 \%$ moving to or approaching full load. For example, at $50 \%$ engine load the values of blends 90/WPPO5/E5, 80/WPPO10/E10, 70/WPPO15/E15, 60/WPPO20/E20, 50/WPPO25/E25 were $22 \mathrm{ppm}, 21 \mathrm{ppm}, 20 \mathrm{ppm}, 18 \mathrm{ppm}$ and $15 \mathrm{ppm}$ respectively compared to full load with $35 \mathrm{ppm}, 34 \mathrm{ppm}, 32 \mathrm{ppm}, 29 \mathrm{ppm}$ and $26 \mathrm{ppm}$. This leads to the conclusion that at high engine loads the values of $\mathrm{NO}_{\mathrm{x}}$ emissions are significantly high for all the blends od WPPO, ethanol and fuel additive.

The UHC emissions from the blends 90/WPPO5/E5 and 80/WPPO10/E10 had higher values and from the graph plot in Fig.7 show almost similar and identical values as CD test fuel. However, the general trend reported by the graph in Fig. 7 is that as the blend ratio increased there was significant reduction of UHC emissions observed across all the test fuels irrespective the engine load condition.

\section{CONCLUSION}

○ The general trend reported by the graph in Fig.7 is that as the blend ratio increased there was significant reduction of UHC emissions observed across all the test fuels irrespective the engine load condition.

- The graph plot in Fig. 6 shows that as the blend ratio increased there was direct increase in the emissions of $\mathrm{NO}_{\mathrm{x}}$ across all the blended test fuels. However, blend 90/WPPO5/E5 reported the lowest values of $\mathrm{NO}_{\mathrm{X}}$ emissions compared to all the other blends that were tested in this experiment.

$\circ$ The graph in Fig.5 shows that as the blend ratio and engine load increased $\mathrm{CO}_{2}$ emissions increased, but compared to CD their emission levels are still lower and almost identical.

$\circ$ Fig. 4 shows that as the engine load and the blend ratio increased there is an increase in the carbon monoxide emissions across the all engine loads and within the blends and CD test fuel.

$\circ$ The graph in Fig.3 shows that as the engine load increased from $25 \%$ to full load (100\%) the graph curves of EGT tend toward unitary, similar and identical to the values of CD test. This 
can be concluded that the blends of WPPO and ethanol with fuel additives have identical temperature characteristics to those of CD test fuel especially as the engine load hits $75 \%$ heading to $100 \%$ (full load).

- Fig.2 indicates that as the blend ratio and engine load increased, there was increase in BTE across the blends of WPPO but with a decrease in the BTE within the blends.

- The BSFC across all the test fuels showed a decrease as the blend ratio increased for all WPPO blends. Although from the graph in Fig. 1 the closeness of the values and the packed graph reveal a close resemblance to BSFC characteristics for the blends of WPPO, ethanol and with fuel additives compared to $\mathrm{CD}$ test fuel.

\section{REFERENCES}

[1] M. Börjesson, E. O. Ahlgren, R. Lundmark, and D. Athanassiadis, "Biofuel futures in road transport-A modeling analysis for Sweden," Transportation Research Part D: Transport and Environment, vol. 32, pp. 239-252, 2014.

[2] L. Benbrahim-Tallaa, R. A. Baan, Y. Grosse, B. Lauby-Secretan, F. El Ghissassi, V. Bouvard, et al., "Carcinogenicity of diesel-engine and gasoline-engine exhausts and some nitroarenes," ed: Elsevier, 2012.

[3] L. V. Giles, C. Carlsten, and M. S. Koehle, "The effect of pre-exercise diesel exhaust exposure on cycling performance and cardio-respiratory variables," Inhalation toxicology, vol. 24, pp. 783-789, 2012.

[4] W. B. Innes, "Effect of nitrogen oxide emissions on ozone levels in metropolitan regions," Environmental science \& technology, vol. 15, pp. 904-912, 1981.

[5] R. E. Hester and R. M. Harrison, Air quality in urban environments vol. 28: Royal Society of Chemistry, 2009.

[6] A. Mills and S. Elouali, "The nitric oxide ISO photocatalytic reactor system: measurement of NOx removal activity and capacity," Journal of Photochemistry and Photobiology A: Chemistry, vol. 305, pp. 29-36, 2015.

[7] J. Ou, Z. Yuan, J. Zheng, Z. Huang, M. Shao, Z. Li, et al., "Ambient ozone control in a photochemically active region: short-term despiking or long-term attainment?," Environmental science \& technology, vol. 50, pp. 5720-5728, 2016.

[8] D. Damodharan, A. P. Sathiyagnanam, B. R. Kumar, and K. C. Ganesh, "Cleaner emissions from a DI diesel engine fueled with waste plastic oil derived from municipal solid waste under the influence of n-pentanol addition, cold EGR, and injection timing," Environmental Science and Pollution Research, pp. 1-15, 2018.

[9] B. R. Kumar and S. Saravanan, "Use of higher alcohol biofuels in diesel engines: A review," Renewable and Sustainable Energy Reviews, vol. 60, pp. 84-115, 2016.

[10] L. Zhu, Y. Xiao, C. Cheung, C. Guan, and Z. Huang, "Combustion, gaseous and particulate emission of a diesel engine fueled with n-pentanol (C5 alcohol) blended with waste cooking oil biodiesel," Applied Thermal Engineering, vol. 102, pp. 73-79, 2016.

[11] I. Yusri, R. Mamat, G. Najafi, A. Razman, O. I. Awad, W. Azmi, et al., "Alcohol based automotive fuels from first four alcohol family in compression and spark ignition engine: A review on engine performance and exhaust emissions," Renewable and Sustainable Energy Reviews, vol. 77, pp. 169-181, 2017.

[12] K. Owen and T. Coley, "Automotive fuels reference book," 1995.

[13] E. Alptekin and M. Canakci, "Characterization of the key fuel properties of methyl ester-diesel fuel blends," Fuel, vol. 88, pp. 75-80, 2009.

[14] S. Pinzi, M. Redel-Macías, D. Leiva-Candia, J. Soriano, and M. Dorado, "Influence of ethanol/diesel fuel and propanol/diesel fuel blends over exhaust and noise emissions," Energy Procedia, vol. 142, pp. 849-854, 2017. 
[15] D. Damodharan, A. Sathiyagnanam, D. Rana, B. R. Kumar, and S. Saravanan, "Extraction and characterization of waste plastic oil (WPO) with the effect of n-butanol addition on the performance and emissions of a DI diesel engine fueled with WPO/diesel blends," Energy conversion and management, vol. 131, pp. 117-126, 2017.

[16] R. Geyer, J. R. Jambeck, and K. L. Law, "Production, use, and fate of all plastics ever made," Science advances, vol. 3, p. e1700782, 2017.

[17] K. Zhang, M. R. Sawaya, D. S. Eisenberg, and J. C. Liao, "Expanding metabolism for biosynthesis of nonnatural alcohols," Proceedings of the National Academy of Sciences, vol. 105, pp. 20653-20658, 2008.

[18] A. F. Cann and J. C. Liao, "Pentanol isomer synthesis in engineered microorganisms," Applied microbiology and biotechnology, vol. 85, pp. 893-899, 2010.

[19] Y. Dekishima, E. I. Lan, C. R. Shen, K. M. Cho, and J. C. Liao, "Extending carbon chain length of 1-butanol pathway for 1-hexanol synthesis from glucose by engineered Escherichia coli," Journal of the American Chemical Society, vol. 133, pp. 11399-11401, 2011.

[20] M. Shahabuddin, A. Liaquat, H. Masjuki, M. Kalam, and M. Mofijur, "Ignition delay, combustion and emission characteristics of diesel engine fueled with biodiesel," Renewable and Sustainable Energy Reviews, vol. 21, pp. 623-632, 2013.

[21] A. Imran, M. Varman, H. Masjuki, and M. Kalam, "Review on alcohol fumigation on diesel engine: a viable alternative dual fuel technology for satisfactory engine performance and reduction of environment concerning emission," Renewable and Sustainable Energy Reviews, vol. 26, pp. 739-751, 2013.

[22] R. Andersson, M. Boutonnet, and S. Järås, "Higher alcohols from syngas using a K/Ni/MoS2 catalyst: Trace sulfur in the product and effect of H2S-containing feed," Fuel, vol. 115, pp. 544-550, 2014.

[23] J. Sun, Q. Cai, Y. Wan, S. Wan, L. Wang, J. Lin, et al., "Promotional Effects of Cesium Promoter on Higher Alcohol Synthesis from Syngas over Cesium-Promoted $\mathrm{Cu} / \mathrm{ZnO} / \mathrm{Al} 2 \mathrm{O} 3$ Catalysts," ACS Catalysis, vol. 6, pp. 5771-5785, 2016.

[24] Y. Liu, K. Murata, M. Inaba, I. Takahara, and K. Okabe, "Mixed alcohols synthesis from syngas over Cs-and Ni-modified $\mathrm{Cu} / \mathrm{CeO} 2$ catalysts," Fuel, vol. 104, pp. 62-69, 2013.

[25] L. Li, J. Wang, Z. Wang, and J. Xiao, "Combustion and emission characteristics of diesel engine fueled with diesel/biodiesel/pentanol fuel blends," Fuel, vol. 156, pp. 211-218, 2015.

[26] B. Masum, H. Masjuki, M. A. Kalam, S. Palash, and M. Habibullah, "Effect of alcoholgasoline blends optimization on fuel properties, performance and emissions of a SI engine," Journal of Cleaner Production, vol. 86, pp. 230-237, 2015.

[27] M. Karabektas and M. Hosoz, "Performance and emission characteristics of a diesel engine using isobutanol-diesel fuel blends," Renewable Energy, vol. 34, pp. 1554-1559, 2009.

[28] J. Campos-Fernández, J. M. Arnal, J. Gómez, and M. P. Dorado, "A comparison of performance of higher alcohols/diesel fuel blends in a diesel engine," Applied energy, vol. 95, pp. 267-275, 2012.

[29] A. N. Ozsezen, A. Turkcan, C. Sayin, and M. Canakci, "Comparison of performance and combustion parameters in a heavy-duty diesel engine fueled with iso-butanol/diesel fuel blends," Energy Exploration \& Exploitation, vol. 29, pp. 525-541, 2011.

[30] Y. Ren, Z. Huang, H. Miao, Y. Di, D. Jiang, K. Zeng, et al., "Combustion and emissions of a DI diesel engine fuelled with diesel-oxygenate blends," Fuel, vol. 87, pp. 2691-2697, 2008.

[31] M. Lapuerta, R. Garcia-Contreras, J. Campos-Fernández, and M. P. Dorado, "Stability, lubricity, viscosity, and cold-flow properties of alcohol- diesel blends," Energy \& fuels, vol. 24, pp. 4497-4502, 2010.

[32] E. Koivisto, N. Ladommatos, and M. Gold, "Systematic study of the effect of the hydroxyl functional group in alcohol molecules on compression ignition and exhaust gas emissions," Fuel, vol. 153, pp. 650-663, 2015. 
[33] S. M. Gaida, A. Liedtke, A. H. W. Jentges, B. Engels, and S. Jennewein, "Metabolic engineering of Clostridium cellulolyticum for the production of n-butanol from crystalline cellulose," Microbial cell factories, vol. 15, p. 6, 2016.

[34] S. H. Desai, C. A. Rabinovitch-Deere, Z. Fan, and S. Atsumi, "Isobutanol production from cellobionic acid in Escherichia coli," Microbial cell factories, vol. 14, p. 52, 2015.

[35] C. Formighieri, "Cyanobacteria as a platform for direct photosynthesis-to-fuel conversion," in Solar-to-fuel conversion in algae and cyanobacteria, ed: Springer, 2015, pp. 31-38.

[36] E. Ofuonye, K. Kutin, and D. T. Stuart, "Engineering Saccharomyces cerevisiae fermentative pathways for the production of isobutanol," Biofuels, vol. 4, pp. 185-201, 2013.

[37] C. D. Rakopoulos, A. M. Dimaratos, E. G. Giakoumis, and D. C. Rakopoulos, "Investigating the emissions during acceleration of a turbocharged diesel engine operating with bio-diesel or n-butanol diesel fuel blends," Energy, vol. 35, pp. 5173-5184, 2010.

[38] C. Jin, M. Yao, H. Liu, F. L. Chia-fon, and J. Ji, "Progress in the production and application of n-butanol as a biofuel," Renewable and Sustainable Energy Reviews, vol. 15, pp. 4080-4106, 2011.

[39] L. Zhu, C. Cheung, W. Zhang, and Z. Huang, "Combustion, performance and emission characteristics of a DI diesel engine fueled with ethanol-biodiesel blends," Fuel, vol. 90, pp. 1743-1750, 2011.

[40] M. Mani, G. Nagarajan, and S. Sampath, "Characterisation and effect of using waste plastic oil and diesel fuel blends in compression ignition engine," Energy, vol. 36, pp. 212-219, 2011.

[41] Q. Zhang, M. Yao, Z. Zheng, H. Liu, and J. Xu, "Experimental study of n-butanol addition on performance and emissions with diesel low temperature combustion," Energy, vol. 47, pp. 515$521,2012$.

[42] S. H. Park, J. Cha, H. J. Kim, and C. S. Lee, "Effect of early injection strategy on spray atomization and emission reduction characteristics in bioethanol blended diesel fueled engine," Energy, vol. 39, pp. 375-387, 2012.

[43] X. Wang, C. Cheung, Y. Di, and Z. Huang, "Diesel engine gaseous and particle emissions fueled with diesel-oxygenate blends," Fuel, vol. 94, pp. 317-323, 2012.

[44] Z. Chen, J. Liu, Z. Han, B. Du, Y. Liu, and C. Lee, "Study on performance and emissions of a passenger-car diesel engine fueled with butanol-diesel blends," Energy, vol. 55, pp. 638-646, 2013.

[45] J. Campos-Fernandez, J. M. Arnal, J. Gomez, N. Lacalle, and M. P. Dorado, "Performance tests of a diesel engine fueled with pentanol/diesel fuel blends," Fuel, vol. 107, pp. 866-872, 2013.

[46] V. Soloiu, M. Duggan, S. Harp, B. Vlcek, and D. Williams, "PFI (port fuel injection) of nbutanol and direct injection of biodiesel to attain LTC (low-temperature combustion) for lowemissions idling in a compression engine," Energy, vol. 52, pp. 143-154, 2013.

[47] Z. Chen, J. Liu, Z. Wu, and C. Lee, "Effects of port fuel injection (PFI) of n-butanol and EGR on combustion and emissions of a direct injection diesel engine," Energy conversion and management, vol. 76, pp. 725-731, 2013.

[48] L. Wei, C. Cheung, and Z. Huang, "Effect of n-pentanol addition on the combustion, performance and emission characteristics of a direct-injection diesel engine," Energy, vol. 70, pp. 172-180, 2014.

[49] G. Kumar, G. Srinivas, and A. K. Ch, "Experimental Investigations on Diesel Engine Fueled With Tyre Pyrolysis Oil and Diesel Blends," International Journal of Emerging Trends in Engineering and Development, vol. 1, 2013.

[50] S. Saravanan, "Effect of exhaust gas recirculation (EGR) on performance and emissions of a constant speed DI diesel engine fueled with pentanol/diesel blends," Fuel, vol. 160, pp. 217226, 2015. 
[51] J. Devaraj, Y. Robinson, and P. Ganapathi, "Experimental investigation of performance, emission and combustion characteristics of waste plastic pyrolysis oil blended with diethyl ether used as fuel for diesel engine," Energy, vol. 85, pp. 304-309, 2015.

[52] P. S. Kumar and G. Sankaranarayanan, "Investigation on environmental factors of waste plastics into oil and its emulsion to control the emission in DI diesel engine," Ecotoxicology and environmental safety, vol. 134, pp. 440-444, 2016.

[53] B. R. Kumar and S. Saravanan, "Effects of iso-butanol/diesel and n-pentanol/diesel blends on performance and emissions of a DI diesel engine under premixed LTC (low temperature combustion) mode," Fuel, vol. 170, pp. 49-59, 2016.

[54] S. Xiaoyan, Y. Yunbo, H. Hong, S. Shuai, D. Hongyi, and L. Rulong, "Combination of biodiesel-ethanol-diesel fuel blend and SCR catalyst assembly to reduce emissions from a heavy-duty diesel engine," Journal of Environmental Sciences, vol. 20, pp. 177-182, 2008.

[55] F. Aydın and H. Öğüt, "Effects of using ethanol-biodiesel-diesel fuel in single cylinder diesel engine to engine performance and emissions," Renewable Energy, vol. 103, pp. 688-694, 2017.

[56] K. Lawyer, A. Ickes, T. Wallner, D. Ertl, R. Williamson, S. Miers, et al., "Blend Ratio Optimization of Fuels Containing Gasoline Blendstock, Ethanol, and Higher Alcohols (C3C6): Part I-Methodology and Scenario Definition," SAE Technical Paper 0148-7191, 2013.

[57] C. Vilarinho, F. Castro, and M. de Lurdes Lopes, WASTES-Solutions, Treatments and Opportunities II: Selected Papers from the 4th Edition of the International Conference on Wastes: Solutions, Treatments and Opportunities, Porto, Portugal, 25-26 September 2017: CRC Press, 2017.

Main Author: Samwel Semakula Maroa received his bachelor of technology in automotive maintenance engineering from the University of Eastern Africa Baraton in Kenya in 1998. He has 19 years of working experience in the transport, manufacturing and road construction industries as a vehicle maintenance engineer manager. Currently he is completing a master of science in mechanical engineering program at the University of KwaZulu Natal in Durban South Africa. He has greater interest in emissions, energy studies and renewable energy, and has four publications in a reputable international journal.

Co Author: Dr. Freddie L. Inambao holds a Master of Science (M.Sc.) and Ph.D. in Mechanical Engineering with specialization in Thermodynamics and Internal Combustion Engines from Volgograd Polytechnic Institute, Russia. He has lectured in several universities in Southern Africa including the University of Zambia, University of Botswana, University of Durban-Westville (before the merger with the University of Natal) and currently a Senior Lecturer in the Discipline of Mechanical Engineering, Howard College, University of KwaZulu-Natal, Durban, South Africa. 